Egypt. Acad. J. Biolog. Sci., 9(1):19 - 26 (2018)

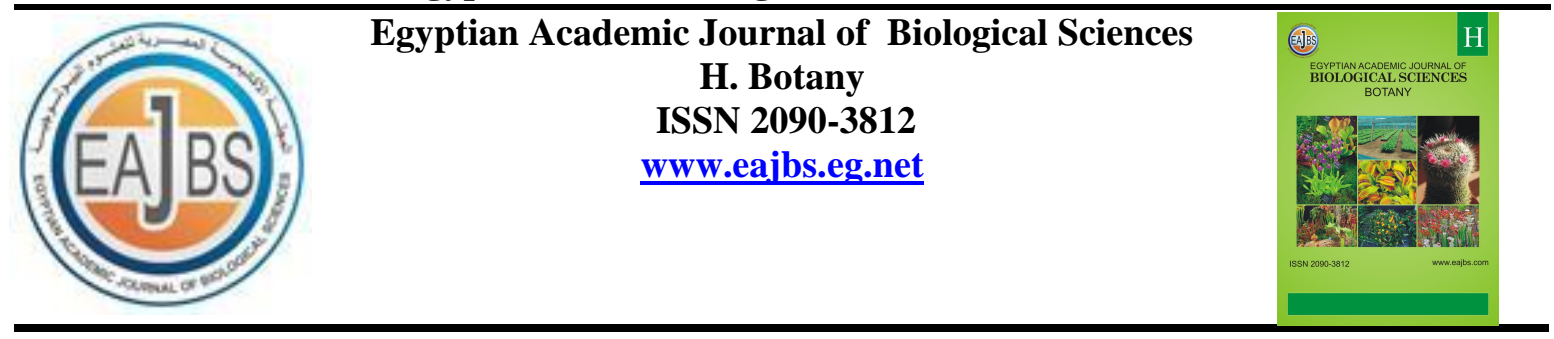

\title{
Response of Some Egyptian and Iraqi Wheat Cultivars to Mineral and NanFertilization
}

\author{
Gomaa, M. A., F. I. Radwan, E. E. Kandil and M. A.F. Al-Msari \\ Plant Production Department, Faculty of Agriculture (Saba Basha), Alexandria University, \\ Egypt
}

ARTICLE INFO

Article History

Received: $25 / 1 / 2018$

Accepted: 27/2/2018

Keywords:

Egyptian; Iraqi; wheat; cultivars; yield; mineral; Nano; fertilization

\section{ABSTRACT}

Two field experiments were conducted at the Experimental Farm of Faculty of Agriculture (Saba- Basha), Abess Region, Alexandria University, Egypt, during two seasons of 2016/2017 and 2017/2018 to study the response of some wheat cultivars to mineral and nanofertilization. The experimental design was split- split plot system with three replicates. The main plots were occupied by the three soil mineral fertilizer NPK treatments at the rate of " 100,75 , and $50 \%$."While, subplots contain three foliar application of nanofertilizer NPK fertilizer treatments " 100,75 and 50\%". Meanwhile, the four wheat cultivars "Sakha 93, Gemmeiza 11, AL-Rasheed and Abu Ghareb" are distributed at random in sub- subplots. plant height, spike length $(\mathrm{cm})$, number of spikes $/ \mathrm{m}^{2}$, number of spikelets /spike, number of grains/spike, 1000grains weight (g), grain yield, straw yield (t/ha.), harvest index (HI \%) and protein content were recorded in both seasons. The obtained results revealed that fertilized wheat cultivar Sakha 93 by $75 \%$ soil application of mineral fertilization by NPK with foliar application of Nano- fertilizers (NPK) increased yield and its components of the wheat crop under the environmental conditions of Alexandria Governorate.

\section{INTRODUCTION}

Wheat (Triticum aestivum L.) is one of the most important cereal crops in the world. It is the main food for more than one-third of the world population; it contributes more calories and protein in the world diet than any other food crops. There is a need to increase wheat grain yield to enhance food security. The government in Egypt aimed to face the human needs. In this respect, it can be increased the wheat production by horizontal and vertical extension. Wheat cultivation in Egypt is about 1.3 million ha and the average yield of wheat reached about $6.6 \mathrm{t} / \mathrm{ha}$. While, the cultivated area in Iraq is about 920 thousand ha

with an average yield about $3.3 \mathrm{t} / \mathrm{ha}$. On the otherwise, the cultivated area in the World reached about 220.1 million ha with an average of 3.4 t/ha (FAO, 2016) 
Conventional fertilizers are generally applied on the crops by either spraying or broadcasting. Excess utilizes of fertilizers decrease soil micro-flora lessens nitrogenfixation. Subsequently, it is important to optimize the utilization of chemical fertilization to full fill the crop nutrient supplement and to reduce the risk of environmental pollution (Tilman et al. 2002). In this manner, it is necessary to test the other methods to provide the necessary nutrients for growth and yield of the crop, while keeping the soil structure in the great shape and environment clean (Miransari, 2011).

Use Nano-fertilizer for control of nutrient release could be considered as an effective way to achieving sustainable agriculture and environment. Nanotechnology has provided the feasibility of exploring the nanoscale or nanostructured materials as a fertilizer carrier or controlled - release vector for the building of the so-called smart fertilizers as new facilities to enhance the nutrient use efficiency and reduce the cost of environmental pollution (Chinnamuth and Boopati, 2009). A nano fertilizer alludes to a product in nanometer regime that delivers nutrient to the crops. For, example encapsulation, inside nanomaterials coated with a thin protective polymer film or in the form of particles or emulsions of nanoscale dimensions. Surface coating of nanomaterials on fertilizer particles hold the material more strongly due to the surface tension than the ordinary surfaces and in this way made a difference in the controlled release (Brady and Weil, 1999). Using nano- potash fertilizer as the source of potassium in rice, which resulted in an increasing number of grains/panicle. They conducted that wheat and corn with nano coating fertilizer and slow release of the same to crops has improved yield as well as effective recovery of $\mathrm{N}$ fertilizer (Subbarao et al., 2013).

An increase in yield due to foliar application of Nano particles640 mg/ha application of foliar application (40ppm concentration) of Nano phosphorus gave $80 \mathrm{~kg} / \mathrm{ha}$ $\mathrm{P}$ equivalent yield of Cluster bean and pearl millet under the arid environment (Tarafdar $e t$ al., 2014). Nano- fertilizers on the growth and yield of selected cereals observed that the full recommended rate of conventional dose Nano fertilizers (FRR-CF+FRR-NF) enhanced the plant height, chlorophyll content, number of reproductive tillers, panicles and spikelet's in rice (Jyothi et al., 2017). Significant increases in plant height, spikes number/m2, spikelets number/spike, grains number/spike, 1000- kernel weight, grain, straw, and biological yields/fed., as well as harvest index (\%) using nano- fertilizer + amino acids during both growing seasons. Meanwhile, the applied mineral fertilizer, alone; gave the lowest mean values of the studied traits. However, "Sids 12" cultivar recorded the highest means values of the studied characters. Spray "Sids 12" cultivar by nano- fertilizer and amino acids; recorded the highest mean values of yield and its components. On the other hand, "Giza 168" cultivar, possessed the lowest ones (Kandil and Marie 2017).

The objective of this investigation is to estimate some wheat cultivars productivity under the effect of mineral and nano-fertilization.

\section{MATERIALS AND METHODS}

Two experiments were carried out at the Experimental Farm of Faculty of Agriculture (Saba Basha), Abess Region, Alexandria University, Egypt, during two seasons of 2016/2017 and 2017/2018. This study aimed to investigate the response of four wheat cultivar to mineral and nano- fertilization.

The preceding crop was maize in the two growing seasons. Soil samples of the experimental sites were taken at the depth of $(0-30 \mathrm{~cm})$. Physical and chemical analysis are presented in Table (1) and were determined according to the method described by Chapman and Pratt (1978). 
Table 1. Some physical and chemical properties of the experimental soil in 2016/2017 and 2017/2018 seasons

\begin{tabular}{|c|c|c|}
\hline \multirow[t]{2}{*}{ Soil properties } & \multicolumn{2}{|c|}{ Season } \\
\hline & $2016 / 2017$ & $2017 / 2018$ \\
\hline \multicolumn{3}{|l|}{ A) Mechanical analysis: } \\
\hline Clay \% & 39.0 & 38.0 \\
\hline Silt $\%$ & 32.0 & 34.0 \\
\hline Sand \% & 29.0 & 28.0 \\
\hline Soil texture & \multicolumn{2}{|c|}{ Clay loam soil } \\
\hline \multicolumn{3}{|l|}{ B) Chemical properties } \\
\hline $\mathrm{PH}(1: 1)$ & 8.20 & 8.31 \\
\hline E.C. $(\mathrm{ds} / \mathrm{m})$ & 3.60 & 3.70 \\
\hline \multicolumn{3}{|l|}{ 1) Soluble cations $(1: 2)(\mathrm{cmol} / \mathrm{kg}$ soil $)$} \\
\hline $\mathrm{K}^{+}$ & 1.52 & 1.54 \\
\hline $\mathrm{Ca}^{++}$ & 9.40 & 8.70 \\
\hline $\mathrm{Mg}^{++}$ & 15.00 & 15.60 \\
\hline $\mathrm{Na}^{++}$ & 10.50 & 11.00 \\
\hline \multicolumn{3}{|l|}{ 2) Soluble anions $(1: 2)(\mathrm{cmol} / \mathrm{kg}$ soil $)$} \\
\hline $\mathrm{CO}_{3}^{--}+\mathrm{HCO}_{3}^{-}$ & 5.20 & 5.30 \\
\hline $\mathrm{Cl}^{-}$ & 18.00 & 19.00 \\
\hline $\mathrm{SO}_{4}^{-}$ & 13.50 & 12.50 \\
\hline Calcium carbonate $(\%)$ & 6.50 & 7.00 \\
\hline Total nitrogen $\%$ & 1.00 & 0.91 \\
\hline Available phosphorus (mg/ kg) & 3.70 & 3.55 \\
\hline Organic matter $(\%)$ & 1.41 & 1.40 \\
\hline
\end{tabular}

Each experimental design was a split-split plot design with three replicates, the main plots contain three Soil mineral NPK fertilizer treatments " 100,75 , and 50\%) form the recommended rates. While, sub-plots contain three foliar application of nanofertilizer NPK fertilizer treatments (100, 75 and 50\%) form the recommended rates. Meanwhile, the four wheat cultivars "Sakha 93, Gemmeiza 11, AL-Rasheed and Abu Ghareb are distributed at random within the sub- subplots.

Treatments (100, 75 and $50 \%)$ of mineral Nitrogen fertilizer at the rate of 168, 126 and $84 \mathrm{~kg} \mathrm{~N} / \mathrm{ha}$., was added in two doses. The first dose (1/3 of dose from N/ha.) was added with the first irrigation (25 days after sowing), the second dose ( $2 / 3$ of dose N/ha.) was added with the second irrigation ( 25 days after the first dose). In the two experiments $\mathrm{N}$ - fertilizer was added on the form of urea $(46.5 \% \mathrm{~N})$. Super phosphate fertilizer $(100,75$ and 50\%) was applied before sowing at the rates of 60, 45 and $30 \mathrm{~kg} \mathrm{P}_{2} \mathrm{O}_{5} /$ ha. Potassium fertilizer treatments $(100,75$ and $50 \%$ ) were applied before sowing (during seedbed preparation) at rate of 60,45 and $30 \mathrm{~kg} \mathrm{~K}_{2} \mathrm{O} / \mathrm{ha}$. (100\%) in the form of potassium sulphate $\left(48 \% \mathrm{~K}_{2} \mathrm{O}\right)$. Foliar application of Nano- fertilizer for NPK was sprayed two times at the rate of $(5 \mathrm{~kg} / \mathrm{ha}$.).

Each subplot size was $10.50 \mathrm{~m}^{2}$ ( $3 \mathrm{~m}$ in length and $3.5 \mathrm{~m}$ in width). The grains of the tested two Egyptian and two Iraqi wheat cultivars were obtained from wheat Research Section of Agriculture Research Center, Ministry of Agriculture in Egypt and Iraq, respectively.

Sowing dates were $10^{\text {th }}$ and $5^{\text {th }}$ November in both seasons, respectively, while, seeding rate was $168 \mathrm{~kg}$ grains/ha., first irrigation was applied at 25 days after sowing and then plants were irrigated every 25 days till the dough stage. 
Table (2). Structure of nano fertilizer (as the foliar application)

\begin{tabular}{l|c|c}
\hline \multirow{2}{*}{ Element } & \multicolumn{2}{|c}{ Compound name (nano- fertilizer) } \\
\cline { 2 - 3 } & Potacrystal & Phospho one \\
\hline $\mathrm{K}_{2} \mathrm{O}$ & $36 \%$ & $28 \%$ \\
$\mathrm{P}_{2} \mathrm{O}_{5}$ & $2 \%$ & $40 \%$ \\
Amino acids & $5 \%$ & $5 \%$ \\
Seaweed extracts & - & $2 \%$ \\
Vitamins & $1 \%$ & $1 \%$ \\
Total nitrogen & $5 \%$ & $5 \%$ \\
Micronutrients $(\mathrm{Br}, \mathrm{Zn}, \mathrm{Mn}, \mathrm{Co}$, and Mo) & $2 \%$ & - \\
\hline
\end{tabular}

Recorded data include plant height, spike length $(\mathrm{cm})$, number of spikes $/ \mathrm{m}^{2}$, number of spikelets /spike, number of grains/spike, 1000-grains weight (g), grain yield, straw yield ( $\mathrm{t} / \mathrm{ha}$.), harvest index ( $\mathrm{HI} \%)$ and protein content.

All collected data were subjected to analysis of variance according to Gomez and Gomez (1984). All statistical analysis was performed using analysis of variance technique by means of CoStat computer software package (CoStat, Ver. 6.311., 2005). The least significant differences (LSD at 0.05) were used to compare the treatment means.

\section{RESULTS AND DISCUSSION}

The data in Table (3) reveals the effect of soil application of mineral fertilization (NPK) and foliar application of Nano- fertilizer and their interaction during 2016/2017 and $2017 / 2018$ seasons on plant height $(\mathrm{cm})$, number of spikes $/ \mathrm{m}^{2}$, number of grains/spike and 1000- grain weight (gm) for four wheat cultivars.

The results are shown in Table (3) indicated that the rate $(100 \%)$ produced significantly highest values of plant height $(84.9$ and $95.1 \mathrm{~cm})$, number of spikes $/ \mathrm{m}^{2}(247.6$ and 317.9 spikes), number of grains/spike (61.2 and 62.1 grains) and 1000- grain weight (52.4 and $51.4 \mathrm{gm}$ ) in both seasons, respectively. While the lowest ones for plant height $(83.9$ and $93.9 \mathrm{~cm})$, number of spikes $/ \mathrm{m}^{2}$ (207.4 and 247.3 spikes), number of grains/spike (51.8 and 54.3grains) and 1000- grain weight (54.3 and $46.8 \mathrm{gm}$ ) was resulted from $50 \%$ mineral fertilizer in the first and second seasons, respectively.

In addition, $75 \%$ nano- fertilizer (NPK) gave the highest values of plant height (89.8 and $100.1 \mathrm{~cm})$, number of spikes $/ \mathrm{m}^{2}$ (252.5 and 305.1 spikes), number of grains/spike (55.7 and 56.7 grains) and 1000- grain weight (50.0 and $49.8 \mathrm{gm}$ ) in both seasons, respectively. Meanwhile, the lowest ones for plant height $(83.3$ and $92.9 \mathrm{~cm})$, number of spikes $/ \mathrm{m}^{2}$ (211.9 and 262.3 spikes), number of grains/spike (55.1 and 56.0 grains) and 1000- grain weight (48.0 and $47.9 \mathrm{gm})$ was resulted from $50 \%$ mineral fertilizer in the first and second seasons, respectively as shown in (Table 3). Foliar application of micronutrients achieved the significant effect on yield and protein content. They are needed in trace amounts, but their adequate supply improves nutrients availability and positively affects the cell physiological that is reflected in yield (Toyama et al., 2001). These results are in agreement with those reported by Subbarao et al. (2013); Tarafdar et al. (2014); Kandil and Marie (2017) who indicated that using nano- fertilizer increased growth of wheat.

Table (3) indicated that wheat cultivar Sids 12 gave the highest plant height (87.6 and $97.5 \mathrm{~cm})$, number of spikes $/ \mathrm{m}^{2}$ (233.2 and 286.7 spikes), number of grains/spike $(57.1$ and 58.6 grains) and 1000- grain weight (50.9 and $50.3 \mathrm{gm}$ ) in both seasons, respectively. On the other hand, AL-Rasheed cultivar recorded the lowest plant height (83.5 and 92.1 $\mathrm{cm}$ ), number of spikes $/ \mathrm{m}^{2}$ (227.0 and 278.6 spikes), while Abu- Ghraib cultivar recorded the lowest number of grains/spike (54.1 and 56.6 grains) and 1000- grain weight (45.2 and $45.1 \mathrm{gm})$ in the first and second seasons, respectively. These differences between wheat 
cultivars may be due to genetic differences makeup between the three cultivars. Raza et al. (2012); Al-Temimi et al. (2013); Bakry et al. (2013) found highly significant differences between wheat cultivars under their studies for yield and its components.

The first and second order of the interaction were shown in Table (3), as significant or not significant at LSD at 0.05 in both seasons.

Table 3. Plant attributes for four wheat cultivars as affected by the application of soil mineral, foliar nanofertilizers and their interaction during 2016/2017 and 2017/2018 seasons

\begin{tabular}{|c|c|c|c|c|c|c|c|c|}
\hline \multirow[t]{2}{*}{ Treatments } & \multicolumn{2}{|c|}{ Plant height $(\mathrm{cm})$} & \multicolumn{2}{|c|}{ Number of spikes $/ \mathrm{m}^{2}$} & \multicolumn{2}{|c|}{ Number of grains/spike } & \multicolumn{2}{|c|}{ 1000- grain weight (gm) } \\
\hline & $2016 / 2017$ & $2017 / 2018$ & $2016 / 2017$ & $2017 / 2018$ & $2016 / 2017$ & $2017 / 2018$ & $2016 / 2017$ & $2017 / 2018$ \\
\hline Minearl & & & & & & & & \\
\hline $100 \%$ & $89.1 \mathrm{a}$ & $97.2 \mathrm{a}$ & $247.6 \mathrm{a}$ & $317.9 \mathrm{a}$ & $61.2 \mathrm{a}$ & $62.1 \mathrm{a}$ & $52.4 \mathrm{a}$ & $51.4 \mathrm{a}$ \\
\hline $75 \%$ & $84.9 \mathrm{~b}$ & $95.1 \mathrm{~b}$ & $234.9 \mathrm{~b}$ & $279.3 \mathrm{~b}$ & $53.9 \mathrm{~b}$ & $54.7 \mathrm{~b}$ & $47.3 \mathrm{~b}$ & $48.0 \mathrm{~b}$ \\
\hline $50 \%$ & $83.9 \mathrm{~b}$ & $93.9 \mathrm{~b}$ & $207.4 \mathrm{c}$ & $247.3 \mathrm{c}$ & $51.8 \mathrm{c}$ & $54.3 \mathrm{c}$ & $46.8 \mathrm{~b}$ & $46.3 \mathrm{~b}$ \\
\hline Nan & & & & & & & & \\
\hline $100 \%$ & $84.8 \mathrm{~b}$ & $93.2 \mathrm{~b}$ & $225.5 \mathrm{~b}$ & $277.3 \mathrm{~b}$ & $56.0 \mathrm{a}$ & $58.4 \mathrm{a}$ & $48.4 \mathrm{~b}$ & $48.1 \mathrm{~b}$ \\
\hline $75 \%$ & $89.8 \mathrm{a}$ & $100.1 \mathrm{a}$ & $252.5 \mathrm{a}$ & $305.1 \mathrm{a}$ & $55.7 \mathrm{a}$ & $56.7 \mathrm{a}$ & $50.0 \mathrm{a}$ & $49.8 \mathrm{a}$ \\
\hline $50 \%$ & $83.3 \mathrm{~b}$ & $92.9 \mathrm{~b}$ & $211.9 \mathrm{c}$ & $262.3 \mathrm{c}$ & $55.1 \mathrm{~b}$ & $56.0 \mathrm{~b}$ & $48.0 \mathrm{~b}$ & $47.9 \mathrm{~b}$ \\
\hline Sids 12 & $87.6 \mathrm{a}$ & $97.5 \mathrm{a}$ & $233.2 \mathrm{a}$ & $286.7 \mathrm{a}$ & $57.1 \mathrm{a}$ & $58.6 \mathrm{a}$ & $50.9 \mathrm{a}$ & $50.3 \mathrm{a}$ \\
\hline Gemmeiza 11 & $86.1 \mathrm{a}$ & $96.0 \mathrm{a}$ & $227.0 \mathrm{~b}$ & $278.6 \mathrm{~b}$ & $57.0 \mathrm{a}$ & $57.3 \mathrm{a}$ & $50.5 \mathrm{a}$ & $50.1 \mathrm{a}$ \\
\hline Al-Rasheed & $83.5 \mathrm{~b}$ & $92.1 \mathrm{~b}$ & $229.5 \mathrm{~b}$ & $279.7 \mathrm{~b}$ & $54.3 \mathrm{~b}$ & $55.7 \mathrm{~b}$ & $48.6 \mathrm{~b}$ & $48.7 \mathrm{~b}$ \\
\hline Abu-Ghraib & $86.6 \mathrm{a}$ & $96.1 \mathrm{a}$ & $233.2 \mathrm{~b}$ & $281.2 \mathrm{~b}$ & $54.1 \mathrm{~b}$ & $56.6 \mathrm{~b}$ & $45.2 \mathrm{c}$ & $45.1 \mathrm{c}$ \\
\hline $\mathrm{A} \times \mathrm{B}$ & $*$ & $*$ & $*$ & $*$ & $*$ & $*$ & * & * \\
\hline $\mathrm{A} \times \mathrm{C}$ & ns & ns & $*$ & $*$ & ns & ns & $*$ & $*$ \\
\hline $\mathrm{B} \times \mathrm{C}$ & ns & ns & $*$ & $*$ & $*$ & ns & $*$ & $*$ \\
\hline $\mathrm{A} \times \mathrm{B} \times \mathrm{C}$ & $*$ & * & $*$ & $\mathrm{~ns}$ & ns & $\mathrm{ns}$ & $*$ & $*$ \\
\hline
\end{tabular}

Means of each factor designated by the same letter are not significantly different at $5 \%$ using least significant difference (L.S.D.) ns: Not Significant *: Significant at 0.05 level of probability

The results in Table (4) revealed the effect of soil application of mineral fertilization (NPK) and foliar application of Nano- fertilizer on straw yield ( $\mathrm{t} / \mathrm{ha}$ ), grain yield (t/ha), harvest index (HI \%) and grain protein \% for four wheat cultivars and their interaction during 2016/2017 and 2017/2018 seasons.

Table (4) cleared that the rate $100 \%$ of soil application of mineral NPK produced significantly highest values of straw yield (7.6 and 7.5t/ha), grain yield (5.2 and 5.1t/ha), harvest index (42.6 and 40.5\%) and grain protein (9.8 and 10.1\%)in both seasons, respectively. While the lowest ones for straw yield (7.6 and $7.5 \mathrm{t} / \mathrm{ha})$, grain yield (4.7 and $39.7 \mathrm{t} / \mathrm{ha}$ ), harvest index (39.7 and $37.6 \%$ ) and grain protein $(8.1$ and $8.4 \%)$ has resulted from $50 \%$ mineral fertilizer in the first and second seasons, respectively. Soil application is the ideal method of nutrient supplement use different fertilizers. It could be needed attention when selecting method of fertilizer applications are how long the fertilizer will last in the soil, soil texture, soil salinity and plant sensitive, salt content and $\mathrm{pH}$ of the amendment. It is well known that the negative soil particles affect the adsorption of mineral nutrients. The anion exchange capacity of the most agricultural soils is small compared to exchange capacity. Phosphate ions bind to soil particles containing $\mathrm{Al}$ or iron because the positively charged $\mathrm{Fe}^{2+}, \mathrm{Fe}^{3+}$ and $\mathrm{Al}^{3+}$ have $\mathrm{OH}^{-}$group that exchange with phosphate. (Taiz and Zeiger, 2010).

In addition, foliar application of $100 \%$ nano- fertilizer (NPK) gave the highest values of straw yield (7.5 and $7.4 \mathrm{t} / \mathrm{ha})$, grain yield (5.4 and $5.3 \mathrm{t} / \mathrm{ha})$, harvest index $(42.1$ and $39.5 \%)$ and grain protein $(9.9$ and $10.1 \%$ ) in both seasons, respectively. Meanwhile the lowest ones for straw yield (7.2 and 7.0 t/ha), grain yield (4.9 and $4.8 \mathrm{t} / \mathrm{ha}$ ), harvest index (40.4 and $38.0 \%$ ) and grain protein $(8.3$ and $8.6 \%$ ) was resulted from $50 \%$ mineral fertilizer in the first and second seasons, respectively (Table 4). These results are in 
harmony with those reported by Subbarao et al. (2013); Jyothi et al.(2017); Kandil and Marie (2017) who indicated that using nano- fertilizer increased the growth of the crop.

The presented results are shown in Table (4) revealed that wheat cultivars have differed significantly on studied characters in both seasons. Whereas, the cultivar Sids 12 achieved the highest straw yield (7.5 and $7.3 \mathrm{t} / \mathrm{ha})$, grain yield (5.3 and $5.2 \mathrm{t} / \mathrm{ha})$, and harvest index (41.4 and 38.9\%) but Gemmeiza 11 gave highest grain protein (9.5 and 9.8 $\%$ )in both seasons, respectively. On the other hand, AL-Rasheed cultivar recorded the lowest straw yield (7.2 and 7.1 t/ha), grain yield (5.0 and $4.9 \mathrm{t} / \mathrm{ha})$, harvest index (40.5 and $38.2 \%$ ) and grain protein (9.8 and $10.1 \%$ ), while Abu- Ghraib cultivar recorded the lowest straw yield (7.6 and $7.5 \mathrm{t} / \mathrm{ha}$ ), grain yield (5.2 and $42.6 \mathrm{t} / \mathrm{ha}$ ), and harvest index (42.6 and 40.5\%) but Al- Rasheed cultivar recorded the lowest value of grain protein (8.9 and $9.2 \%$ ) in the first and second seasons, respectively. These findings were in harmony with those obtained by these differences between wheat cultivars may be due to genetic differences make up between the three cultivars. Raza et al. (2012); Al-Temimi et al. (2013);Bakry et al. (2013) found highly significant differences between wheat cultivars under their studies for yield and its components. There were significant differences between the two varieties for most studied characteristics (Abd El-Ghany et al., 2013).

Foliar fertilizers sprayed directly on to leaves. It is used for the supply of trace elements. The foliar application can reduce the time lag between application and uptake by the plant during the rapid growth phase. It can also circumvent the problem of restricted uptake of a nutrient from the soil. Uptake of nutrients may be more efficient with this method as compared to soil application where they get absorbed on soil particles and hence are less available to the root system (Taiz and Zeiger, 2010)

The first and second order of the interaction were shown in Table (4), as significant or not significant at LSD at 0.05 in both seasons.

Table 4. Plant attributes for four wheat cultivars as affected by the application of soil mineral, foliar nano- fertilizers and their interaction during 2016/2017 and 2017/2018 seasons.

\begin{tabular}{|c|c|c|c|c|c|c|c|c|}
\hline \multirow[t]{2}{*}{ Treatments } & \multicolumn{2}{|c|}{ Straw yield (t/ha.) } & \multicolumn{2}{|c|}{ Grain yield (t/ha.) } & \multicolumn{2}{|c|}{ Harvest index (\%) } & \multicolumn{2}{|c|}{ Grain protein $\%$} \\
\hline & $2016 / 2017$ & $2017 / 2018$ & $2016 / 2017$ & $2017 / 2018$ & $2016 / 2017$ & $2017 / 2018$ & $2016 / 2017$ & $2017 / 2018$ \\
\hline $100 \%$ & $7.6 \mathrm{a}$ & $7.5 \mathrm{a}$ & $5.2 \mathrm{a}$ & $5.1 \mathrm{~b}$ & $42.6 \mathrm{a}$ & $40.5 \mathrm{a}$ & $9.8 \mathrm{a}$ & $10.1 \mathrm{a}$ \\
\hline $75 \%$ & $7.3 \mathrm{a}$ & $7.4 \mathrm{a}$ & $5.4 \mathrm{a}$ & $5.5 \mathrm{a}$ & $40.9 \mathrm{~b}$ & $37.7 \mathrm{~b}$ & $9.7 \mathrm{a}$ & $9.9 \mathrm{a}$ \\
\hline $50 \%$ & $7.1 \mathrm{~b}$ & $6.9 \mathrm{~b}$ & $4.7 \mathrm{~b}$ & $4.8 \mathrm{c}$ & $39.7 \mathrm{~b}$ & $37.6 \mathrm{~b}$ & $8.1 \mathrm{~b}$ & $8.4 \mathrm{~b}$ \\
\hline $100 \%$ & $7.5 \mathrm{a}$ & $7.4 \mathrm{a}$ & $5.4 \mathrm{a}$ & $5.3 \mathrm{a}$ & $42.1 \mathrm{a}$ & $39.5 \mathrm{a}$ & $9.9 \mathrm{a}$ & $10.1 \mathrm{a}$ \\
\hline $75 \%$ & $7.3 \mathrm{a}$ & $7.2 \mathrm{a}$ & $5.1 \mathrm{~b}$ & $5.0 \mathrm{~b}$ & $40.7 \mathrm{~b}$ & $38.3 \mathrm{~b}$ & $9.8 \mathrm{a}$ & $9.9 \mathrm{a}$ \\
\hline $50 \%$ & $7.2 \mathrm{~b}$ & $7.0 \mathrm{~b}$ & $4.9 \mathrm{c}$ & $4.8 \mathrm{~b}$ & $40.4 \mathrm{~b}$ & $38.0 \mathrm{~b}$ & $8.3 \mathrm{~b}$ & $8.6 \mathrm{~b}$ \\
\hline Sids 12 & $7.5 \mathrm{a}$ & $7.3 \mathrm{a}$ & $5.3 \mathrm{a}$ & $5.2 \mathrm{a}$ & $41.4 \mathrm{a}$ & $38.9 \mathrm{a}$ & $9.3 \mathrm{ab}$ & $9.6 \mathrm{ab}$ \\
\hline Gemmeiza 11 & $7.4 \mathrm{a}$ & $7.2 \mathrm{~b}$ & $5.1 \mathrm{ab}$ & $5.1 \mathrm{a}$ & $40.9 \mathrm{a}$ & $38.5 \mathrm{a}$ & $9.5 \mathrm{a}$ & $9.8 \mathrm{a}$ \\
\hline AL-Rasheed & $7.3 \mathrm{ab}$ & $7.2 \mathrm{~b}$ & $5.1 \mathrm{ab}$ & $5.0 \mathrm{~b}$ & $41.3 \mathrm{a}$ & $38.9 \mathrm{a}$ & $9.1 \mathrm{bc}$ & $9.4 \mathrm{bc}$ \\
\hline Abu-Ghraib & $7.2 \mathrm{~b}$ & $7.1 \mathrm{c}$ & $5.0 \mathrm{~b}$ & $4.9 \mathrm{~b}$ & $40.5 \mathrm{~b}$ & $38.2 \mathrm{~b}$ & $8.9 \mathrm{c}$ & $9.2 \mathrm{c}$ \\
\hline$A \times B$ & $*$ & * & $*$ & * & $*$ & * & $*$ & $*$ \\
\hline$A \times C$ & $*$ & $*$ & $*$ & $*$ & $*$ & $*$ & $*$ & $*$ \\
\hline $\mathrm{B} \times \mathrm{C}$ & $\mathrm{ns}$ & ns & $*$ & $*$ & $*$ & $*$ & $*$ & $*$ \\
\hline $\mathrm{A} \times \mathrm{B} \times \mathrm{C}$ & $\mathrm{ns}$ & $\mathrm{ns}$ & $*$ & $*$ & $*$ & $*$ & $\mathrm{~ns}$ & ns \\
\hline
\end{tabular}

Means of each factor designated by the same letter are not significantly different at $5 \%$ using least significant difference (L.S.D.)

ns: Not Significant

*: Significant at 0.05 level of probability.

\section{CONCLUSION}

It was concluded from the present results that sowing wheat cultivar Sakha 93 with fertilizing $75 \%$ as soil application of mineral fertilization by NPK with foliar application 
of Nano- fertilizers (NPK) which increased yield and its components of the wheat crop under Alexandria Governorate conditions.

\section{REFERENCES}

Abd El-Ghany, H.M., Ebtsam A. El-Housini and M.H.M. Afifi (2013).Effect of certain macronutrients foliar application on growth, yield and nutrients content of grains for two bread wheat varieties in sandy soil.J. Appl. Sci. Res., 9(2): 1110-1115.

Al-Temimi, H. N. Gh., I. S. Alsaadawi and A. W. Al-Shahwany (2013). Screening of bread wheat (Triticum aestivum L.) genotypes for drought tolerance under field conditions. A Thesis Submitted to the Biology Dept. College of Science Baghdad Univ.

Bakhtiari, Mitra, P. Moaveni and B. Sani (2015). The effect of iron nanoparticles spraying time and concentration on wheat. Biol. Forum Int. J., 7(1):679-683.

Bakry, B. A., T. A. Elewa, M. F. El-Kramany and A. W. Wali (2013). Effect of humic and ascorbic acids foliar application on yield and yield components of two wheat cultivars grown under newly reclaimed sandy. Int. J. Agron. \& Pl. Prod. 4(6):1125-1133.

Chapman, H.D. and P.F. Pratt (1978). Methods of Analysis for Soils, Plants and Water. Univ. of California, Prical Publication, Vol. 4030, 12-19.

Chinnamuthu, C. R. and P. M. Boopati (2009). Nanotechnology and Agro ecosystem. Madras Agricultural Journal. 96: 17- 31.

CoStat Ver. 6.311 (2005). Cohort software798 light house Ave. PMB320, Monterey, CA93940, and USA. email: info@cohort.com and Website: http://www.cohort.com/DownloadCoStatPart2.html

F.A.O. (2016). Food and Agriculture Organization Statistics, FAOSTAT. www.fao.org/faostat.

Jyothi, T.V and N.S. Hebsur (2017). Effect of Nanofertilizers on growth and yield of selected cereals. Agricultural Reviews. 38(2): 112-120.

Kandil, E. E., Eman A. O. Marie (2017). Response of some wheat cultivars to nano-, mineral fertilizers and amino acids foliar application. Alexandria Science Exchange J., 38(1):54-68.

Miransari, M. (2011). Soil microbes and plant fertilization. Applied Microbiological Biotechnol., 92: 875-885.

Raza, M.A. S., M. F. Saleem,I. H. Khan,M. Jamil,M. IjazandM.A. Khan(2012). Evaluating the drought stress tolerance efficiency of wheat (Triticum aestivum L.) cultivars. Russ. J. Agric. Socio-Econ. Sci., 12 (12):41- 46.

Subbarao, C. V., G. Kartheek and D. Sirisha (2013). "Slow Release of Potash Fertilizer Through Polymer Coating". Inter. J. Appl. Sci. and Engin.,11(1): 25-30.

Taiz, L. and E. Zeiger (2010). Plant physiology, $5^{\text {th }}$ edn. Sinauer Associates Inc., Massaschusetts, 781pp.

Tarafdar, J. C., R. Raliya, H. Mahawar and I. Rathore (2014). Development of zinc nanofertilizer to enhance crop production in pearl millet (Pennisetum americanum). Agric. Res. J. 3(3):257-262.

Tilman, D., J. Knops, D. Wedin and Reich, P. (2002). Plant diversity and composition: effects on productivity and nutrient and dynamics of experimental grasslands. In: Loreau M, Naeem S, Inchausti P (Eds), Biodiversity and ecosystem functioning. Oxford University press, Oxford, pp: 21-35.

Toyama, S. E. A., Amal, A. El-Hofi and H. Ashoush (2001). Yield and technological characteristics of some wheat varieties as affected by $\mathrm{N}$ fertilizer and seed rates Agric. Sci. Mansoura Univ., 25 (50: 2449- 2467. 


\section{ARABIC SUMMARY}

\section{إستجابة بعض أصناف القمح المصرية والعراقية للتسميد المعدني والنانو}

محمود عبد العزيز جمعة - فتحي ابراهيم رضوان - عصام إسماعيل إسماعيل قتنديل - محمد عبد الحسين فياض المساري

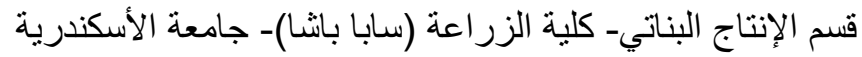

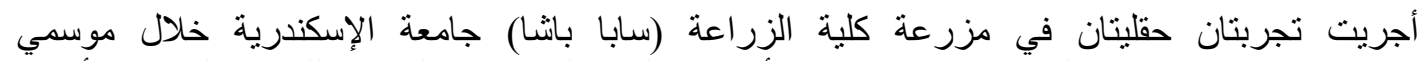

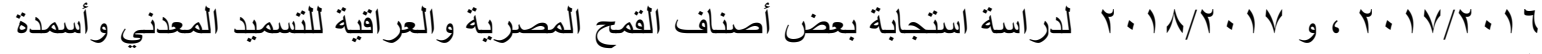

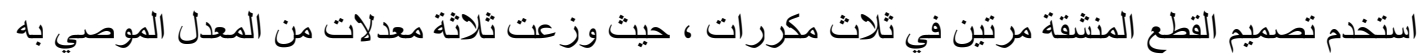

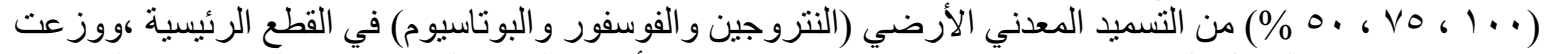

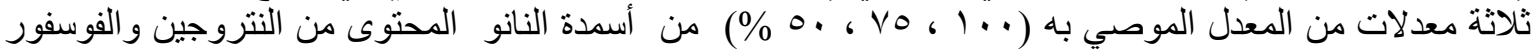

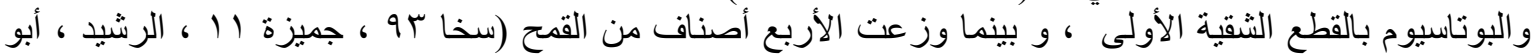
غريب) بالقطع الثقية الثانية.

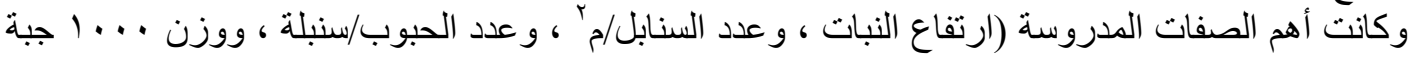

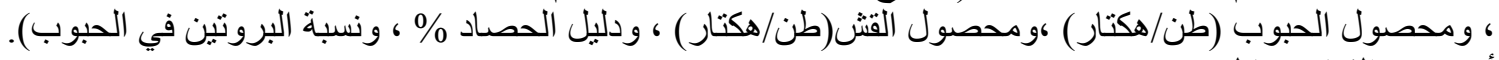

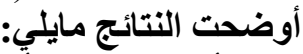

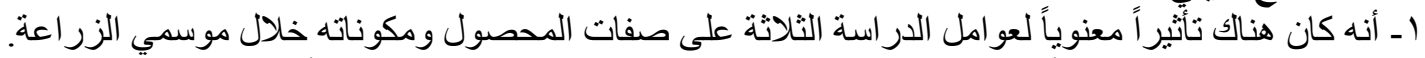

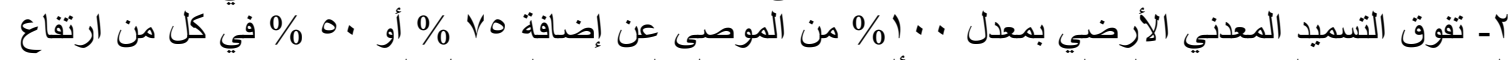

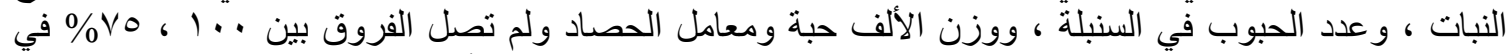

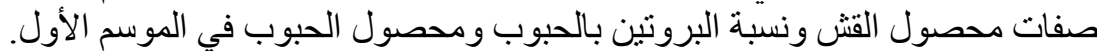

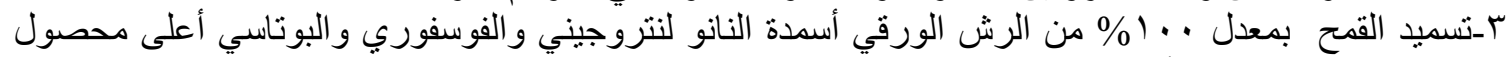

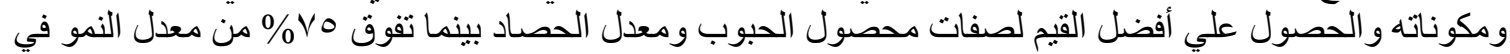
باقي الصفات تحت الدار أسة.

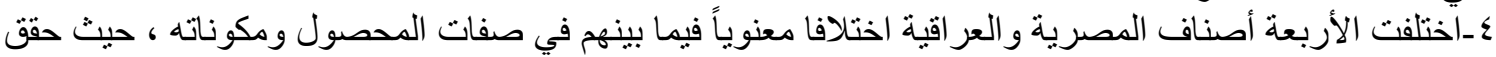

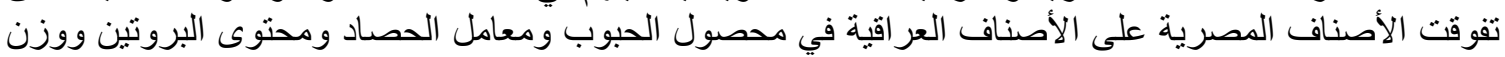
الألف حبة و عدد الحبوب/السنبلة.

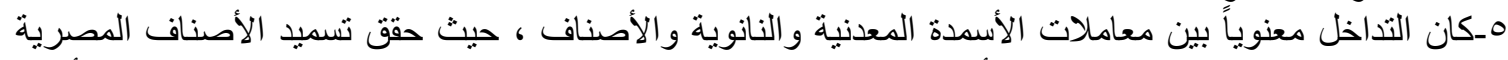

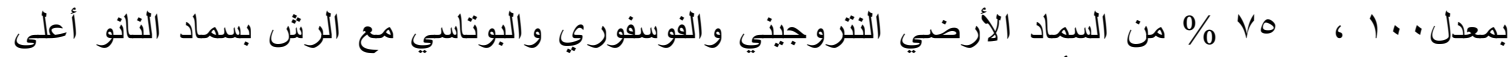
محصول ومكوناته الحصول علي أفضل القيم للصفاد التصات التي تم در استها.

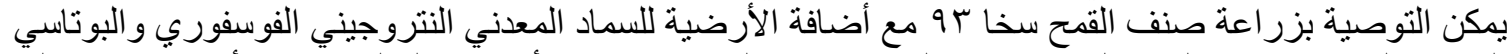

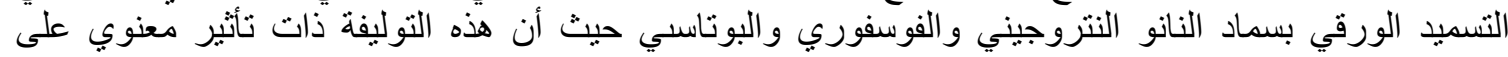
المحصول ومكو ناته ومحتوي حبوب من البروتين تحت الظروف النئن البيئية لمنطقة الدر اسة. 